\title{
IBN ‘ARABI; EPISTEMOLOGI DAN KONTROVERSI
}

\author{
Abdul Mukit Ridwan \\ Universitas Ibn Khaldun Bogor dan Peserta Kaderisasi Seribu Ulama \\ Baznas-Dewan Dakwah Islamiyah \\ e-mail:imaz_iim.imaz99@yahoo.com
}

\begin{abstract}
Abstrak:
Perbincangan tentang tasawuf, sufi dan para pemukanya memang tidak pernah menemukan kata usai dan selesai. Karena ia mempunyai jangkauan meluas, akar mendalam yang harus benarbenar di perhatikan secara seksama oleh mereka yang ingin membahasnya. Terutama jika perbincangan tersebut berkaitan dengan salah satu pemuka tasawuf semacam Muhyiddin Ibn 'Arabì yang sudah tidak diragukan lagi otoritas dan kapasitas keilmuannya baik di Barat maupun di Timur. Di Timur, ia dikenal sebagai pemuka tasawuf yang jujur dalam perkataan dan menepatinya dengan tindakan dalam samudera rahasia ketuhanan. Sedangkan di Barat ia dikenal sebagai tabib yang dapat mengobati penyakit ganas Barat dengan ilmu dan pengetahuannya. Namun betapapun kekayaan wawasan, ilmu dan pengetahuan yang dimilikinya, popularitasnya sebagai hamba yang begitu mencintai Tuhannya, terdapat beberapa sisi beliau yang harus segera dibahas tuntaskan karena menyangkut akidah dan agama. Yaitu seperti sangkaan bahwa beliau adalah pendiri agama cinta, penganut pluralisme, tokoh dalam transendent unity of religions serta pegiat paham wihdat al-wujūd. Oleh sebab itu, penulis mengajukan judul, Ibn 'Arabi: epistemology dan kontroversi, agar dapat membahas tuntaskan masalah diatas. Metode yang penulis tempuh adalah library research dengan mengetengahkan pribadi Ibn 'Arabi dalam ratusan karya dan tulisannya untuk menjelaskan dan menuntaskan dugaan-dugaan dimaksud sehingga tuntas dan selesai. Semoga Allah memberi Taufiq dan kepada-Nya penulis pasrahkan segalanya.
\end{abstract}

Kata kunci: Ibn 'Arabi, epistemologi, pluralisme, wihdat al-wujūd

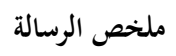

فإن الحوار عن التصوف والصوفي ورجاله مما لا غاية فيه, ليس له بداية ولا غهاية. لأن

له مرامي واسعة وجذور عميقة التي لا بد لكل الباحثين فيه أن يدققوا النظر وتشددوا 


$$
\begin{aligned}
& \text { في التحقيق عليه. لاسيما إذا كان الحوار متعلقا بأحدر كبار رجال التصوف مثل } \\
& \text { محي الدين ابن عربي الذي لا يشك له غبار بالصيت والإشتهار فن المعارف والعلوم } \\
& \text { شرقا وغربا. لقد تعرف الشرق بصدقه في القول والحال, ويعد هو من أكابر أصحاب } \\
& \text { الأقوال والأحوال, فله قول صادق وحال مشرق في الأسرار الربانية. وفى الجانب } \\
& \text { الآخر, عرفه الغرب بمعارفه العميقة وعلومه الدقيقة في الحب والخمبة, وتمنى به إطفاء }
\end{aligned}
$$

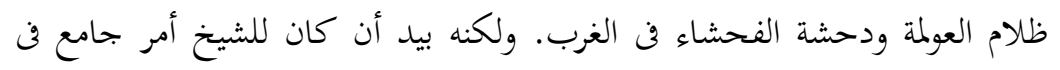

$$
\begin{aligned}
& \text { العلم والمعرفة, في القول والحال, فله وجوه لا بد التثبت فيها, والكشف عنف عن غطنائها }
\end{aligned}
$$

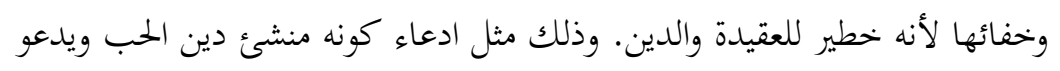

$$
\begin{aligned}
& \text { إلى وحدة الوجود بل إلى وحدة الأديان واستلم على التعددية والتثليث وغير ذلك } \\
& \text { من المفاهيم التي لا بد أن تصحح. ولهذا, قدمت هذا البحث بعنوان: ابن عربي : } \\
& \text { نظرية معرفته والجدال حوله. أقصد ببحثي هذا, أن أقدم ابن عربي بين مؤلفاته } \\
& \text { ومصنفاته وبين الجدال الذي يدور حوله, بالمنهج العلمي المكتبي المبني على مبادئ } \\
& \text { الإعتدال والتوازن, كي يجيب ابن عربي بنفسه ذلك الجحدال وتلك المفاهيم الواردة } \\
& \text { حتى لايبقي بعده ريب وشك وطعن لهذا الرجل العظيم. وإلى الله التوفيق وعليه } \\
& \text { التوكل. } \\
& \text { الكلمة: ابن عربي, نظرية المعرفة, التعددية, وحدة الوجود }
\end{aligned}
$$

\section{Prolog}

Pembicaraan tentang tasawuf memang tidak pernah usai dan selesai. Paling tidak karena dua faktor penting:

Pertama, faktor internal, meliputi, kapasitas orang-orang yang membicarakan tasawuf tidak mengerti dan paham esensinya. Kebanyakan dari mereka menempatkan tasawuf sebagai kajian teori, padahal ia merupakan pengamalan dan aplikasi. Tasawuf adalah ilmu hal, ilmu perilaku, tatakrama, akhlak, dibahasakan oleh al-Ghazali sebagai proses penghormatan yang dzahir dan batin ${ }^{1}$ dan sebagai ilmu bersifat dzauqiyyah (rasa), tidak hanya dibicarakan, didiskusikan dan diperdebatkan semata,

\footnotetext{
${ }^{1}$ Al-GhazāTi, Ayyuha al-Walad al-Muhib, ditahqiq oleh Jamil Ibrahim Habib,(Baghdad, Dar al-Qadisiyah, t.tp), 130
} 
Ibn 'arabī; Epistemologi dan kontroversi

namun harus diamalkan. Kesalah-pahaman tentang tasawuf banyak berasal dari para penganut tasawuf nazari, mereka yang hanya menempatkan tasawwuf sebagai kajian teori.

Selain kapasitas para komentatornya, tidak menutup kemungkinan bahwa tasawuf sebagai aliran khusus, mempunyai persoalan-persoalan rumit dan penuh kontroversi. Seperti paham tentang hulul, wihdät al-wujūd, nazariyāt al-faị̣ (teori emanasi), ishrāq-dalam pandangan masyarakat luassangat erat dengan tasawuf itu sendiri. Hal ini merupakan persoalan tersendiri karena paham-paham yang disebutkan secara luas masih sulit untuk diterima. Apalagi jika paham dimaksud dinisbatkan kepada para ulama yang diakui otoritasnya dalam dunia Islam seperti Ibn 'Arabì.

Kedua, faktor eksternal dari pihak asing, Barat, misalnya dengan memunculkan istilah tasawuf falsafi yang ingin menegaskan eksistensinya dan perbedaannya dengan tasawuf sunni. Kedua faktor di atas, paling tidak akan mempengaruhi setiap orang saat memandang tasawuf.

Hal yang penting diungkap untuk menjawab persoalan di atas adalah dengan menjelaskan epistemologi kaum Sufi. Bagaimana kaum sufi mendapatkan pengetahuan, cara kerja pengetahuan mereka, tahapan-tahapan yang dilakukan sehingga membentuk sebuah perilaku dan keyakinan.

Epistemologi adalah bagian penting dari kajian kesufian, agar dapat diketahui secara jelas mengenai susunan pengetahuan kaum sufi dan bagaimana persoalan-persoalan di atas bisa terjadi.

Salah satu tokoh besar sufi yang sangat erat dikenal dalam kontroversi di atas adalah Muhyiddin Ibn 'Arabì. Tokoh ini memang dikenal luas, baik di Timur maupun di Barat. Di Timur dia dipuja sebagai sufi yang mengajarkan tariqah untuk mencapai pengetahuan hakiki tentang Tuhan sehingga manusia bisa menjadi insan kamil, sedang di Barat dianggap sebagai solusi dari persoalan globalisasi. Karena dianggap berhasil menyatukan cara memandang realitas kehidupan dalam satu semangat dan tujuan. Oleh karena itu, Ibn 'Arabì sering didekatkaan dengan wihdāt alwujūd, bahkan wihdāt al-adyān dan pluralisme agama.

Sangat aneh memang untuk dipercayai begitu saja. Apalagi Ibn 'Arabi adalah tokoh besar, baik di kalangan bangsa Timur maupun Barat. Pengagum dan pengkritiknya sama banyaknya, bahkan mungkin pengagumnya di Indonesia lebih banyak dibanding kritikusnya.

Masih segar di ingat an penulis, saat salah satu dosen menyatakan, jika Ibn 'Arabì dikafirkan, maka banyak ulama nusantara yang kafir. ${ }^{2}$ Menarik,

\footnotetext{
${ }^{2}$ Pernah disampaikan oleh Adian Husaini pada kuliah materi Islamic Worldview di program magister pendidikan Islam.
} 
misalnya ulama Aceh bernama Nuruddin al-Rānirī melalui bukunya, "Hujjät al-Siddiq li Daf'i al-Zindiq"mengkritik klaim wihdàt al-wujūd Hamzah Fanshuri tentang Ibn 'Arabī dengan membela Ibn 'Arabi dari paham tersebut. Karena memang keduanya sama-sama pembela dan pengagum Ibn 'Arabì dengan caranya masing-masing yang tentu berbeda.

Maka, saat ini sikap kritis, selektif (tabayun) perlu untuk dikembalikan kepangkuan tradisi umat. Saat klaim terhadap sesuatu yang belum tentu benar, sangat menjamur. Apalagi terkait dengan salah satu tokoh besar seperti Ibn 'Arabì.

Studi ini berupaya untuk mengembalikan tradisi tersebut. Tradisi yang dibangun atas kaidah:

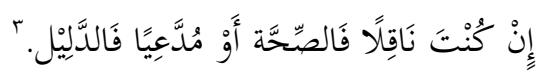

"Apabila anda mengutip data, maka harus dilakukan secara valid (ṣahìh). Dan apabila menyampaikan klaim, maka harus berdasarkan dalil".

Studi ini bertujuan untuk mengungkap sejauh mana klaim-klaim yang ditujukan kepada Ibn 'Arabi bisa dipertanggung-jawabkan secara ilmiah. Sehingga diharapkan nantinya, tidak diterima lagi nama besar ulama yang dicatut dan dijadikan bamper untuk klaim yang tidak berdasar.

Melalui tinjauan epistemologis ini, diharapakan dapat memperoleh penjelasan lengkap tentang pengetahuan sufi, cara kerjanya, serta memberi sudut pandang lain tentang kontroversi-kontroversi yang banyak disandingkan dengan Ibn 'Arabi.

Metode penelitian ialah cara kerja meneliti, mengkaji dan menganalisis objek sasaran penelitian untuk mencari hasil atau kesimpulan tertentu. Karena penelitian ini bersifat studi kepustakaan dalam buku dan tulisan, maka salah satu cara adalah survei literature yaitu mencari dan mempelajai bahan-bahan tertulis yang berkaitan dengan objek kajian dimaksud. Penulis uraikan sebagai berikut;

Penelitian ini berjenis kualitatatif, yaitu dengan penelitian kepustakaan (library research), yaitu dengan menelusuri data pustaka yang ada dalam buku serta melengkapinya dengan pustaka lain yang berhubungan dengan kajian dimaksud. Penelitian ini dilakukan dengan membaca, menelaah, dan menganalisis content buku dan didukung berbagai literatur yang berhubungan dengannnya.

Penelitian ini bersifat deskriptif-analitik, yaitu penelitian yang berfungsi untuk menyelesaikan masalah melalui pengumpulan, penyusunan,

\footnotetext{
${ }^{3}$ Sa'īd Ramaḍān al-Būṭi dalam kitabnya “Kubrā al-Yaqiniyyāt al-Kauniyah: Wujūd al-Khāliq wa Wazífāt al-Maklūq", (Damaskus: Dār al-Fikr, 1997), 34.
} 
dan proses analisa mendalam terhadap data yang ada untuk kemudian dijelaskan dan selanjutnya diberi penilaian. ${ }^{4}$

Data yang digunakan dalam penelitian ini diambil dengan menelusuri, mengumpulkan, dan meneliti berbagai referensi yang berkaitan dengan dengan tema yang diangkat. Sumber data dalam penelitian pustaka ini dibagi menjadi dua, yakni data primer dan data sekunder.

\section{a. Data Primer}

Dalam penelitian ini, yang menjadi data primer adalah buku: Ibn 'Arabi, Rasail Ibn 'Arabì: Syarhu Mabdai al-Thäfān wa Rasāil Ukhrā, tahqqīq: Qasim Muhammad Abbas, Husein Muhammad 'Ājil, Abu Dabi: Majma' al-Tsaqafì, 1998 M.

Ibn 'Arabī, Al-Dzakhāir al-A'lāq fī Sharh Tarjumāni alAsywāq, tahqīq. Muhammad Abd al-Rahmān al-Kurdì, Mesir: Maktbah Kairo, 1968 M

Ibn 'Arabī, Futūhāt al-Makkiyah, ed. Osman Yahia, Kairo: Al-Hay'at al-Mishriyyah al-'ÁAmmah li al-Kitab, 1997 M.

Abd al-Wahab al-Sha'rānī, al-Thabaqāt al-Kubrā, Tarjamah Ibn 'Arabī, Dār al-Ṣadr, 2003 M

Abd al-Wahab al-Sha'rāni. al-Yawāqit wa al-Jawāhir fí Bayāni 'Aqāid al-Akābir, Dār al-Șadr, 2003 M

\section{b. Data Sekunder}

Data sekunder adalah semua data yang berhubungan dengan kajian dimaksud, baik berupa buku, jurnal, artikel-artikel yang tersebar di situs-situs internet, dan data lain yang relevan dengan kajian penelitian ini.

c. Pendekatan

Penelitian ini memakai pendekatan teologis-filosofis. Pendekatan teologis digunakan untuk mengetahui corak pemikiran para pemikir yang karyanya menjadi rujukan penelitian. Sedangkan pendekatan filosofis adalah pendekatan yang bersifat menyeluruh, mendasar, radikal dan speklulatif. Pendekatan ini berguna untuk memahami esensi dan substansi konsep pemikiran Ibn 'Arabi.'

\footnotetext{
${ }^{4}$ Rianto Adi, Metodologi Penelitian Sosial dan Hukum, (Jakarta: Granit, 2004), 128.

5 Juju S. Sumatri, Filsafat Ilmu: Sebuah Pengantar Populer, (Jakarta; Pustaka Sinar Harapan, 1988), 20.
} 
Sesuai dengan sifat penelitian ini (library research), data primer dan sekunder di atas ditelusuri dengan menggunakan metode content analysis (analisis isi). Analisis isi digunakan untuk mengungkap isi dari data-data di atas untuk kemudian disajikan dalam sebuah narasi yang memuat tema dan signifikansi masalah yang penulis kaji. Untuk menggunakan analisis isi ini, penulis menggunakan metode sebagai berikut:

a. Deduktif, yakni menganalisis data yang bersifat umum, untuk kemudian ditarik menjadi kesimpulan yang bersifat khusus. ${ }^{6}$ Metode deduktif ini digunakan untuk menganalisis semua data yang ada dalam buku objek kajian serta data lainnya, kemudian ditarik satu kesimpulan dari data-data tersebut.

b. Induktif, yaitu menganalisis berbagai fakta dan data, kemudian digeneralisasikan menjadi sebuah statemen. ${ }^{7}$ Metode induktif digunakan untuk menganalisis data yang berbentuk argumentasi, klaim maupun lainnya yang ada pada objek kajian penelitian, kemudian ditarik kesimpulan yang bersifat umum.

\section{Biografi Ibn ‘Arabî}

Bernama lengkap Muhammad bin 'Ali ibn Ahmad ibn Abdullah al-Ṭā$\bar{i}$ al-Hātimì. Lahir di Murcia, Andalusia Tenggara, Spanyol pada 17 Ramadan, tahun 560 H/ 28 Juli tahun 1165 M, pada masa Khilafah alMustanjid yang memerintah Murcia dan Valencia. Beliau lahir dari keluarga berpangkat, hartawan dan ilmuwan. Beliau meninggal di Damaskus pada tahun $638 \mathrm{H}$.

Di Sevilla, Ibn 'Arabi mempelajari al-Qur'an, hadis, fikih kepada Ibn Hazm al-Zuhri. Pada usia 30 tahun, ia berkelana ke berbagai kawasan Islam di Andalusia dan kawasan Islam bagian Barat. Berguru kepada Abū Madyān, al-Talimsari, dan Yasmin Mushāniyah. Beliau sempat berjumpa dengan Ibn Rushd di Kordoba. Ibn 'Arabi dianggap sebagai komentator agung (alShārih al-a'dzam) dalam pemikiran Tasawuf. ${ }^{8}$

Disebutkan oleh Dāirat al-Ma'ārif al-Islāmiyah sebagian nama-nama yang mengkritik Ibn 'Arabī, diantaranya: Ibn al-Khayyāth, al-Hāfiz alDhahabī, Ibn Taimiyah, Ibn Iyyās, al- Taftāzanī, 'Alì al-Qārì, Jamaluddin ibn Muhammad ibn Nūruddin. Sedangkan yang membelanya diantaranya

\footnotetext{
${ }^{6}$ Sudatro, Metode Penelitian Filsafat, (Jakarta: Raja Grafindo Persada, 1996), 42.

${ }^{7}$ Suharsimi Ari Kunto, Prosedur Penelitian; Suatu Pendekatan Praktek, cet. ke-10, (Jakarta: PT Rineka Cipta, 1996), 42.

${ }^{8}$ Ibn 'Arabī, Rasāil ibn 'Arabīi: Sharhu Mabdai al-Ṭāfān wa Rasāil Ukhrā, tahqīiq: Qāsim Muhammad Abbās, Husein Muhammad 'Ajil, (Abu Dabi: Majma' al-Thaqafí, 1998M), 9
} 
Ibn 'arabi; Epistemologi dan kontroversi

adalah: Fayruz Abadi, pengarang kamus, Sirājuddin al-Makhzūmī, Kamāluddin al-Zamlakāni, Qathbuddīn al-Hamawì, Șalāhuddin al-Ṣafdi, Shihābuddin Umar al-Suhrawardi, Fakhruddin al-Rāzì, Muhammad alMaghribīi, Jalāluddin al-Suyūțī, Badruddin ibn Jamā'ah, Sirājuddin alBulqini, Taqiyuddin al-Subki dan lainnya. ${ }^{9}$

Pada abad ke 13 H/ 19 M, nama Ibn 'Arabì terbang ke Barat. Di mulai dengan terjemahan terhadap buku-buku karyanya, selesainya terjemahan kitab "Risālah Al-Ahadiyah" -yang diduga ditulis Ibn "Arabì-, dalam bahasa Inggris dan Perancis, merupakan awal persentuhan namanya dengan dunia Barat. Kemudian Orientalis asal Isbania, Miguel Asin Palacios melakukan terjemahan terhadap karya-karya Ibn 'Arabiyang lain, dan menulis tentangnya. Tulisannya berjudul "' ilm al-nafs 'inda Muhyiddin ibn 'Arabî"

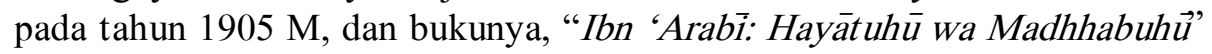
pada tahun 1919 M, yang diterjemahkan oleh Abd al-Rahmān al-Badawī. Kemudian pembicaraan tentang tokoh ini menjadi terkenal dan menyebar melalui buku-buku yang membicarakannya, diantaranya adalah, buku: H. S. Nyberg, Kleinere Schriften des Ibn 'Arabī, Leiden 1919 M; Annemarie Schimmel, Mystical Dimention of Islam, Chapel Hill: The Univeritay of North Carolina, 1975 M; Sayyed H. Naṣr, Three Muslim Sages: AviccenaSuhrawardi-Ibn 'Arabì, New York: Carafan Books, 1964 M; Henry Corbin, Alone with the alone: creative imagination in the Sufism of Ibn 'Arabi, Princeton: Bollingen, 1969 M. ${ }^{10}$

Karya-karya Ibn 'Arabì mencapai sekitar 400 karya. Antara lain adalah "al-Futūhät al-Makkiyah" yang ditulis pada tahun $1201 \mathrm{M}$ saat menunaikan ibadah haji. Karya lainnya adalah "Tarjumān al-Ashwäq” yang ditulis untuk mengenang seorang gadis dari keluarga sufi di Persia. Juga "Fuṣuș al-Hikam", "Shajarat al-Kaun", "Mawāqi' al-Nujūm”dan lainnya.

Ibn 'Arabi dan segudang karyanya tersebut mendapatkan perhatian khusus dari ulama Islam. Misalnya al-Suyūtị dalam "Tanbīh al-Ghabi fí Tabriati Ibn 'Arabì', Sirājuddin al-Makhzūmì dalam, "Kashf al-Ghitā' 'an Asrār Muyiddin", Abd al-Wahhāb al-Sha'rānì dalam, "al-Yawāqit wa alJawāhir" '11

\footnotetext{
${ }^{9}$ Ibn 'Arabī, Rasāil ibn 'Arabìi: Sharhu Mabdai al-Ṭāfān wa Rasāil Ukhrā, tahqīi: Qāsim Muhammad Abbās, Husein Muhammad 'Ajil, (Abu Dabi: Majma' al-Thaqafi, 1998M), 164

${ }^{10}$ Muhammad 'Ā Madhhabuhū, (Suriyah: Halb 'Ashimah li al-Thaqāfah al-Ilmiyah, 2006 M/ 1427 H), 401-402

${ }^{11}$ Terjemah singkat ini didasarkan pada kitab, Abd al-Mun'im al-Hefni, al-Mausū'ah alSüfiyah, Kairo: Dār al-Rashad, 1992; terjemahan Abdurrahmān al-Badawī terhadap karya Miguel Asin Palacios: Ibn 'Arabī: Hayātuhū wa Madhhabahū, Makatabah Injilo al-Mișriyah, 1965, Nașr Hamid Abū Zaid, Hākadhā Takallama ibn 'Arabỉ, dan lainnya.
} 
Ibn 'arabi; Epistemologi dan kontroversi

\section{Tentang Epistemologi}

Epistemologi adalah pembahasan mengenai bagaimana manusia mendapatkan pengetahuan, sumber-sumber pengetahuan, hakikat, jangkauan dan ruang lingkup pengetahuan? Apakah manusia mungkin mendapatkan pengetahuan? Sampai di mana tahap pengetahuan yang mungkin dicapai oleh manusia? ${ }^{12}$

Beberapa pakar lainnya juga mendefinisikan espitemologi, seperti J.A Niels Mulder menuturkan, epistemologi adalah cabang filsafat yang mempelajari tentang watak, batas-batas dan berlakunya dari ilmu pengetahuan. Jacques Veuger mengemukakan, epistemologi adalah pengetahuan tentang pengetahuan dan pengetahuan yang kita miliki tentang pengetahuan kita sendiri bukannya pengetahuan orang lain tentang pengetahuan kita, atau pengetahuan yang kita miliki tentang pengetahuan orang lain. ${ }^{13}$

Ringkasnya, epistemologi sangat erat kaitannya dengan ilmu. Ia adalah cabang filsafat berkenaan dengan cara mendapatkan ilmu, sumber ilmu, jangkauan dan ruang lingkup ilmu. Jadi epistemoogi sufi adalah metode, sumber, jangkauan dan ruang lingkup sufi dalam menempatkan dan memperoleh ilmu.

\section{Epistemologi Ibn 'Arabī}

Ibn 'Arabi menegaskan urgensi ilmu pengetahuan. Bahwa ia merupakan pemberian dari Allah. Siapa yang memperolehnya akan mendapatkan kemuliaan tinggi. :

$$
\text { وأعظم الهبات .. . فالعلم ما جاد به الله على عباده هو العلم, فمن الذاتي والشرف الآخر مكتسب. الله العلم فقد منحه أشرف الصفات }
$$

Dari uraian ini, Ibn 'Arabì ingin membangun paradigma tentang ilmu yang dimaksudkannya. Bahwa ilmu tidak datang sendiri, ia berasal dari Allah SWT Yang Maha Tinggi. Karena berasal dari Allah itu maka, selayaknya dimaksudkan dan didayagunakan untuk kemaslahatan manusia menurut sang pemberi yaitu Allah swt. Dari uraian ini diketahui bahwa ilmu tidak boleh netral dan bebas nilai. Ia harus senantiasa bersesuaian dengan tuntunan Allah dalam al-Qur'an dan penjelasan Nabi Muhammad saw. dalam hadis-hadis. Pembagian ilmu menjadi dhat $\bar{i}$ (pribadi) dan muktasab

\footnotetext{
${ }^{12}$ Jujun Suriasumantri, Filsafat Ilmu Sebuah Pengantar Populer, t.p.(2007), 119

${ }^{13}$ Surajio, Filsafat Ilmu dan Perkembangannya di Indonesia, (Jakarta: Bumi Aksara, 2010), 77

${ }^{14} \mathrm{Ibn}$ 'Arabī, Futūhāt al-Makkiyah, vol. 3, (Kairo: maktabah wahbah, 1999), 361
} 
(diusahakan), menegaskan bahwa manusia dapat dan mampu memeperoleh pengetahuan.

Menurut Ibn 'Arabī, pengetahuan telah ada dalam jiwa manusia yang diperolehnya saat tajalli al-Ilăh $\bar{i}$ (penampakan Tuhan) sewaktu diciptakannya. ${ }^{15}$ Yaitu sejak awal manusia dibekali pengetahuan tentang diri-Nya dan bersaksi akan ketuhanan-Nya. (QS. Al-A'rāf: 172).

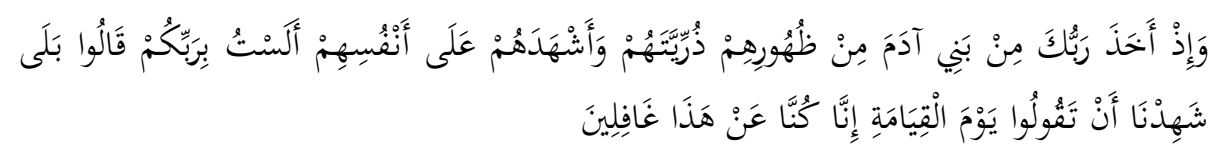

"Dan (ingatlah), ketika Tuhanmu mengeluarkan keturunan anak-anak Adam dari sulbi mereka dan Allah mengambil kesaksian terhadap jiwa mereka (seraya berfirman): "Bukankah aku ini Tuhanmu?" mereka menjawab: "Betul (Engkau Tuban kami), Kami menjadi saksi". (kami lakukan yang demikian itu) agar di hari kiamat kamu tidak mengatakan: "Sesungguhnya Kami (Bani Adam) adalah orang-orang yang lengah terhadap ini (keesaan Tuhan)"

Ibn 'Arabì membagi urgensi ilmu dalam dua kategori (khazanah): pertama, ilmu tentang Allah. Kedua, ilmu tentang alam. ${ }^{16}$ Ilmu tentang Allah merupakan ilmu yang paling penting sedangkan ilmu tentang alam akan membantu manusia lebih mengenal Tuhannya.

Kemudian Ibn 'Arabì menjelaskan pembagian ilmu tersebut secara eksplisit menjadi empat: ilmu rasional (mantīi $\overline{1})$, ilmu matematis (riyāội),

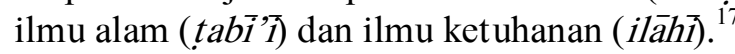

Ketiga, ilmu di atas mempunyai cara kerja sebagai berikut:

Manusia memperoleh pengetahuan melalui panca indera dan perangkat pembantu lainnya. Daya imajinasi (khayal) mengoreksi pengetahuan yang diberikan oleh panca indera, sehingga di alam imajinasi (al-khayal) tersusun berbagai macam pengetahuan. Pengetahun imajinatif tersebut adakalanya tunduk kepada akal atau wahm (prasangka). Jika tunduk kepada akal, maka ia akan mengantarkan manusia pada pengetahuan matematis (riyāọi), namun apabila tunduk pada wahm maka ia akan cepat menghilang dari ingatannya. Allah memberikan manusia daya imajinasi, permualaanya adalah apa yang dilihat manusia dalam mimpi, agar ia cepat

\footnotetext{
${ }^{15}$ Ibn 'Arabì, Futūhāt al-Makkiyah, faṣl; hājat al-nafs ilā al-ilm, vol. 1, (Kairo: maktabah wahbah, 1999), 43

${ }^{16}$ Maysoun Musallatīi, Qirāah Mu'așirah li Afkār ibn 'Arabī, terj. Yūsuf Ṭabbākh, (Swedia: Afanta Publication, 1997),46

17 Ibn 'Arabī, Futūhàt al-Makkiyah, faṣl; hājat al-nafs ilā al-ilm, vol. 1, (Kairo: maktabah wahbah, 1999), 581
} 
sadar untuk menengok alam metafisik, ayahnya bukan terus-menerus bergantung kepada ibunya, alam fisik. ${ }^{18}$

Sedangkan ilmu yang keempat adalah ilmu ketuhanan yang diperitahkan Allah kepada Nabi-Nya agar senantiasa ditambahkan ${ }^{19}$, yaitu ilmu tentang Allah swt. dan berasal dari Allah bukan dari pengetahuan inderawi, diterima akal secara suka rela tanpa argumentasi dan pembuktian, pemberian Allah berupa keimanan, dan akan bertambah melalui penguatan bașirah. $^{20}$

Mengenai cara atau metode memperoleh pengetahuan versi Ibn 'Arabi ada dua: pertama șā'idah (naik), kedua, nāzilah (menurun).

Cara pertama dimulai melalui olahan akal, pikiran manusia yang didapatkan dari panca inderanya. Sedangkan cara kedua, adalah al-faid alilahhi (emanasi ketuhanan) yaitu ilham bukan wahyu. Keduanya sama-sama berasal dari Allah melalui perantara Malaikat-Nya, bedanya nabi melihat malaikat tersebut, sedangkan hamba yang diberi ilham tidak melihatnya. Ilmu tersebut adalah ilmu pemberian (ilmu wahb) yang diterima saat hati dan jiwa seeorang sudah siap, melalui tașfiyah dan tazkiyah yang hanya bisa di rasakan (dhauq).

Ibn 'Arabi menjelaskan bahwa dhauq adalah:

الذوق نتيجة بحربة شخصية يتعرف بها كل فرد إلى الشي ويدرك معناه إدراكا وفهما خاصين."

Dhauq dalam pandangan Sufi bukanlah tingkatan individual yang hanya dapat dinikmati oleh satu orang saja. Namun ia merupakan tingkatan yang juga memberlakukan metode empiris (tajribah) sebagai metode untuk menggapainya. Tingkatan ini juga bukan tingkatan irasional yang hanya bisa dijelaskan oleh iman, namun juga dapat diterima oleh akal.

Dhauq sebagai salah satu tingkatan kematangan spiritual seorang sălik tidak bisa dilepaskan dengan metode empirik. Karena dhauq hanya bisa dirasakan oleh ia yang melakukan proses tersebut. Semua bisa membuktikan dan merasakan kebenaran yang dirasakan oleh șüfí. Hanya perlu syarat

${ }^{18}$ Ibn 'Arabī, Futūhāt al-Makkiyah, fașl; hājat al-nafs ilā al-ilm, vol. 1, (Kairo: maktabah wahbah, 1999), 581

${ }^{19}$ QS Ṭāhā (114):

$$
\text { وَقُلْ رَبِّ زِدْنِي عِلْمًا }
$$

Makna ayat zidni 'ilman yaitu fahman (kepahaman). Ayat ini menekankan pentingnya ilmu dan ulama'. Al-Qurțūbì, al-Jāmi’ li Ahkām al-Qur'àn, vol. 11, Riyāḍ: Dār al-‘Alam al-Kutub, hlm. 250

${ }^{20}$ Ibn 'Arabī, Futūhāt al-Makkiyah, fạsl; hājat al-nafs ilā al-ilm, vol. 1, (Kairo: maktabah wahbah, 1999), 582

${ }^{21}$ Ibn 'Arabì, Futūhāt al-Makkiyah, faṣl; hājat al-nafs ilā al-ilm, vol. 1, (Kairo: maktabah wahbah, 1999), 583 
Ibn 'arabi; Epistemologi dan kontroversi

pengamalan bagi yang masih ragu. Dari sini, bisa dibaca bahwa tasawuf sebagai metode spiritual tidak menjauhi pembuktian ilmiah, bahkan begitu erat dengan salah satu intrumen ilmiah yaitu empiris, lebih dari itu tasawuf bersifat terbuka karena bisa dibuktikan oleh siapa saja.

Sedangkan menurut objek yang diketahuianya, Ibn 'Arabi membagi ilmu menjadi: Ilmu 'aql atau nažr dan ilmu ahwāl yang diperoleh dari aldhauq, dirasakan melalui indera dan masya'ir-nya, kadang tidak bisa diungkapkan dengan kata, namun dipahami secara sangat mendalam, dan ilmu asrār yang hanya diperoleh oleh para nabi. Pengetahuan yang akan mewariskan keyakinan disebut ilmu yaqin, kemudian dengan itu, dapat menyaksikan segala sesuatu sehingga menjadi 'ain al-yaqin, dan selanjutnya Allah bukakan bașirah-nya sehingga mengetahui alasan dan sebab segala sesuatu tersebut dan menjadi haqqu al-yaqin. ${ }^{22}$

Jadi sumber pengetahuan yang digunakan Ibn 'Arabi adalah panca indera (hawas), akal, ilham, dan wahyu.

Dalam mengurai pandangannya tersebut, Ibn 'Arabi mengelaborasi berbagai jenis pengetahuan yang dipahaminya dari berbagai filsafat dan budaya selain sufi. Pada titik ini pemikiran Ibn 'Arabi dianggap bercampur dengan banyak pandangan filsafat Yunani dan Islam, perpaduan pandangan dengan ulama kalam, sufi dan pandangan șāhib al-madhhab ${ }^{23}$, untuk membangun satu pikiran yang dikumpulkan dari pandangan Ibn Masarrah, Jābir Ibn Hayyān, Risalah Ikhwān al-Ṣafā, dan kitab-kitab lain yang dinisbatkan kepada Ismā'iliyyah, dan akidah yang berafiliasi pada kelompok al-Rawaqiyyīn, Failon al-Yahudi, dan pengkikut Plato modern (aflätoniyyīn al-judud). ${ }^{24}$

Padahal jika dicermati bahwa Ibn 'Arabi dalam menguraikan pengetahuan yang diperolehnya dari hasil akulturasi dengan budaya dan peradaban lain, sangat menekankan dan menegaskan landasannya terhadap syariat.

Bisa dilihat dari istilah-istilah "barzakh", 'amā', dan "kalimah" yang memiliki akar dari al-Qur' an dan hadis. Hadis tentang 'amā', sebagai dasar dari al-khayāl, yang merupakan hasil dari jiwa ketuhanan adalah paham yang berbeda dengan Failon al-Yahūdi. Karena Ibn 'Arabi bersandar pada jawaban Rasul atas pertanyaan dari seseorang: ayna kāna rabbunā qabla alyakhluqa al-kaūn (dimana Tuhan kita sebelum alam diciptakan), Rasul menjawab: berada di 'amā' yang di bawah dan di atasnya tidak ada udara

\footnotetext{
${ }^{22}$ Ibn 'Arabīi, Futūhāt al-Makkiyah, fașl; hājat al-nafs ilā al-ilm, vol. 1, (Kairo: maktabah wahbah, 1999),584

${ }^{23}$ Abū Ulā al-Afifî, Min Ayna Istaqa Ibn 'Arabī Falsafatahū al-Süfí, t,t.p, 50

${ }^{24}$ Abū Ulā al-Afífì, Min Ayna Istaqa Ibn 'Arabì Falsafatahū al-Sǘ̄î̀, t,t.p, 20
} 
(kāna fì 'ama' mā tahtahū hawā' wa mā fauqahū hawā'). ${ }^{25}$ Begitu juga pandangan Ibn 'Arabi tentang "kalimah" yang berbeda dengan istilah Logos yang dikemukakan oleh Failon atau lainnya. Ibn 'Arabi melihat bahwa semua al-wujūd pada hakikatnya adalah kalimah Allah yang tidak terbatas. Sebagaimana Isa adalah kalimah Allah yang ditiupkan kepada Maryam. ${ }^{26}$ Begitu juga pandangannya tentang barzakh yang didasarkan firman Allah (QS. al-Rahmān [19-20]). ${ }^{27}$

Memang pandangan filsafat dan pemikiran di luar Islam diadopsi oleh Ibn 'Arabi namun hal tersebut tidak berarti bahwa Ibn 'Arabi menggunakannya untuk dijadikan dasar konstruksi pemikirannya seperti pendapat Abū Ulā al-'Afífî̀ di atas. ${ }^{28}$ Karena menyebutkan sesuatu tidak berarti harus menyetujui atau membenarkannya.

Terlihat misalnya dengan tegas Ibn 'Arabī menempatkan wahyu pada posisi tertinggi di atas akal.

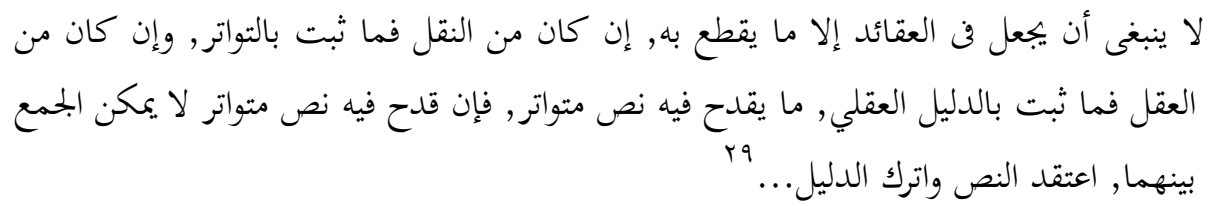

"Dalam urusan akidah, sangat tidak pantas menetapkan apapun kecuali dalil yang dipastikan kebenarannya, baik yang ditetapkan melalui dalil mutawatir atau dalil akal dengan catatan selama keduanya tidak menyalahi nas mutawätir (al-Qur'an dan hadis mutawatir), namun apabila terdapat ketidak sesuaian dengan nas mutawätir yang tidak mungkin diintegrasikan antara keduanya maka, yakinlah terhadap nas dan tinggalkan dalil tersebut".

${ }^{25}$ Hadis ini adalah pertanyaan sahabat bernama Abū Razīn tentang keberadaan Allah, kemudian Rasul menjawab :

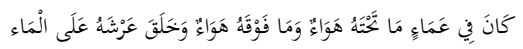

Yazìd bin Hārūn menyatakan bahwa maksud 'amā', adalah tidak ada sesuatu apapun bersama Allah (laisa ma'ahü shai-un). Menurut al-Tirmidhi kualitas hadis ini hasan. Hadis ini diriwayatkan oleh al-Tirmidhi, Sunan al-Tirmidhi, bab min Surah Hüd, hadis no. 3034; Ahmad, Musnad Ahmad, Bab Musnad al-Madaniyyin, Hadis Abi Rizin al-'Uqaili, hadis no. 15599; Ibnu Mājah, Sunan Ibnu Mājah, Bab: Fìma Ankarat al-Jahmiyah, Hadis no. 178 dan riwayat lainnya.

${ }^{26}$ Firman Allah QS. al-Tahrim (12):

${ }^{27}$ Firman Allah QS. al-Rahmān (19-20):

${ }^{28}$ Ibn 'Arabī, Rasāil Ibn 'Arabīi, t.t.p, 28

${ }^{29}$ Ibid, vol. 1, 465 
Khabar mutawātir tidak hanya al-Qur'an, namun juga hadis dan pengetahuan yang disampaikan oleh banyak orang yang tidak mungkin dusta.

Dari uraian panjang di atas, bahwa epistemologi Ibn 'Arabī dapat disimpulkan sebagai berikut:

\begin{tabular}{|c|c|}
\hline \multicolumn{2}{|c|}{ EPISTEMOLOGI IBN ‘ARABI } \\
\hline $\begin{array}{l}\text { Cara manusia untuk mendapatkan } \\
\text { pengetahuan }\end{array}$ & $\begin{array}{l}\text { Pertama șáidah (menaik) yaitu } \\
\text { melalui kumpulan pengetahuan oleh } \\
\text { panca indera, diimajinasikan, diolah } \\
\text { melalui akal dan pikiran. } \\
\text { Kedua, nāzilah (menurun) yaitu } \\
\text { melalui faiḍ al-Ilāhìililham yang } \\
\text { diterima akal. }\end{array}$ \\
\hline $\begin{array}{l}\text { Dapatkah manusia memperoleh } \\
\text { pengetahuan? }\end{array}$ & $\begin{array}{l}\text { Manusia bisa mengetahui bahkan } \\
\text { harus menjadi tahu. Pengetahuan } \\
\text { atau ilmu sudah dibawa manusia } \\
\text { sejak lahir bahkan diberikan Allah } \\
\text { saat pertamakali penciptaannya. Ada } \\
\text { ilmu yang sifatnya dhăti dan } \\
\text { diusahakan (muktasab). Dengan } \\
\text { mengasah pengetahuan dan } \\
\text { tingkatannya ia akan menjadi insan } \\
\text { kamil. }\end{array}$ \\
\hline Sumber Pengetahuan & $\begin{array}{l}\text { Indera, Akal, Ilham, Dan wahyu. } \\
\text { Ilham bukanlah hal yang bersifat } \\
\text { irasional, ia merupakan pengetahuan } \\
\text { tinggi yang diterima oleh akal (supra } \\
\text { rasional), dilatih melalui tasfiyah dan } \\
\text { tazkiyah. Nas al-Mutawātir } \\
\text { merupakan tingkatan pengetahuan } \\
\text { tertinggi, barometer serta penyeleksi } \\
\text { terhadap jenis pengetahuan lainnya. }\end{array}$ \\
\hline
\end{tabular}

\section{A. Pemikiran Ibn 'Arabì}

Pandangan Ibn 'Arabi tentang epistemologi selanjuntnya akan dijadikan sebagai landasan untuk menjawab bebera kontroversi yang dinisbatkan kepadanya yaitu paham pluralisme, dan wihdat al-wujüd. 


\section{Ibn 'Arabỉ dan Pluralisme}

Salah satu gubahan syair Ibn 'Arabỉ yang melegenda dan kontrovesial adalah:

$$
\begin{aligned}
& \text { إذا لم يكن ديني إلى دينه داني } \\
& \text { فمرعي لغزلان وبيت لأوثان } \\
& \text { وألواح توراة ومصحف قرآن } \\
& \text { r. } \\
& \text { ركائبه فالحب ديني وإيماني لوراه }
\end{aligned}
$$

$$
\text { وقد وقد كنت قبل اليوم أنكر صاحبي لرهب }
$$

Artinya:

Aku pernah mengingkari sahabatku,

Karena agamaku berbeda dengan agamanya

(Sekarang) sungguh hatiku telah terbuka, menerima segala bentuk,

Padang rumput bagi rusa, Rumah untuk berhala-berhala

Gereja bagi para pendeta,

Ka'bah untuk mereka yang thawaf

Papan-papan Taurat,

Dan lembaran-lembaran al-Qur'an

Aku memeluk agama yang berdasarkan cinta

Kemanapun ia mengarah

Cinta kepada-Nya

Adalah agama dan keyakinanku

Syair inilah yang diklaim oleh Husein Nashr, William C. Hittick, Frithjof Schuon sebagai pembenar dari konsep "agama perenial", "kebenaran universal" yang transenden pada tataran esoterik dan hanya berbeda pada ranah eksoteriknya saja. ${ }^{31}$

Syair ini pula yang membuat Naṣr Hāmid begitu senang karena menurutnya "agama cinta" ini, adalah obat penyakit globalisasi dan membuat nama besar Ibn 'Arabi diabadikan di Barat menjadi sebuah nama organisasi. $^{32}$

Saat Chittick mengklaim bahwa, Ibn 'Arabī menerima kebenaran semua agama terutama Islam, Kristen dan Yahudi, karena bertujuan sama menuju kebahagian dengan ajaran cintanya, namun perbedaannya hanya

\footnotetext{
${ }^{30}$ Ibn 'Arabī, Al-Dhakhāir al-A'laq fì Sharh Tarjumān al-Ashwāq, tahqīi: Muhammad Abd Rahmān al-Kurdi, (Kairo: t.th.),49-50

${ }^{31}$ Syamsuddin Arif, Orientalis dan Diabolisme Pemikiran, (Jakarta: Gema Insani, 2008), 262. Adian Husaini, Tinjauan Historis: Konflik Yahudi-Kristen-Islam, Jakarta: Gema Insani Press, 2004

${ }^{32}$ Naṣr Hāmid, Hākadhā Takallama Ibn 'Arabī,(Kairo: Pustaka: al-Hay-ah al-Mishriyah al‘'Āmmah li al-Kitāb, 2002), 14
} 
pada tataran pembahasaan sesuai dengan keadaan dan tuntutan yang mempengaruhinya, ${ }^{33}$ di saat yang sama para pemikir muslim seperti Husein Nașr, Nașr Hāmid dan pengikut setianya dengan bangga mengganggukan kepala. Salah satunya adalah Abū 'Ulā al-'Afifí yang terburu-buru mengatakan:

Pemikiran wihdat al-wujūd sudah menyatu dengan Ibn 'Arabī, sehingga dia menafsirkan segala yang di alam wujūd dan keyakinan dari sudut pandang tersebut. Pada alam keyakinan berupa agama-agama, karena itu Ibn 'Arabi melihat bahwa Tuhan dari agama-agama pada hakikatnya adalah satu, itulah alasan mengapa Ibn 'Arabi berpandangan tentang kesatuan-kesatuan agama-agama (wihdat al-adyān/transendent unity of religions). ${ }^{34}$

Satu gubahan sya'ir ini dianggap cukup oleh para pemikir di atas untuk mengklaim bahwa Ibn 'Arabì pengusung pluralisme, seorang perenialis yang mendukung agama perennial, dan setuju dengan konsep transendent unity of religions Fritjof Schuon yang mempertemukan agamaagama pada dimensi esoterik dan hanya berbeda pada dimensi eksoterik, serta membenarkan Nașr Hāmid atas berdirinya "agama cinta".

Padahal ungkapan Ibn 'Arabi tentang agama, akidah, syariat, akhlak yang dipahaminya, bertebaran di pelbagai karyanya yang mencapai 400 karya. Bagaimana dengan pandangan $\mathrm{Ibn}$ 'Arabi di ratusan karyanya tersebut? Bagaimana juga, seorang pemikir yang mengklaim dirinya kelompok ilmiah dan rasional, bisa berhenti dan membuat kongklusi atas satu gubahan syair di bawah syair-syair lainnya yang saling menjelaskan dan berkaitan satu dengan lainnya? Padahal Ibn 'Arabī dengan tegas menyampaikan bahwa, konstruksi pandangannya berkesinambungan antara satu pendapat dengan pendapat lainnya. Tidak kontradiktif (menclamencle), namun terpadu, berkesinambungan dan saling terkait.:

لمعنى... إن مذب في كل ما أورده أني لا أقصد لفظة بعينها دون غيرها- مما يدل على معناها- إلا

"Sesungguhnya madzhabku, dalam setiap penjelasan yang aku uraiakan, aku tidak menghendaki satu kata berdiri sendiri tanpa kata lain yang menjelaskan maksdunya kecuali untuk suatu tujuan".

Begitulah seharusnya seorang ilmuwan memahami cara berpikir seseorang, komperhensif dan menyeluruh, tidak terburu-buru dan gegabah,

${ }^{33}$ William C. Chittick, Dunia Imajinal Ibn 'Arabi: Kreativitas Imajinasi dan Persoalan Diversitas Agama, terj. Ahmad Syahid,( Surabaya: Risalah Gusti, 2001),270-275

${ }^{34}$ Makalah yang disampaikan Abū 'Ulā al-Afífì tentang kitab Futūhāt al-Makkiyah, 165

${ }^{35} \mathrm{Ibn}$ 'Arabì, Futūhàt al-Makkiyah, vol.1, 391 
tidak pula parsial dan sepotong-sepotong. Mengambil potongan yang disukainya dan membuang poongan lain yang tidak sesuai dengan selera.

Maka, sejenak kita tundukan hati dan pikiran, jangan biarkan ego dan kesombongan menguasai diri. Mari kita biarkan Ibn 'Arabī berbicara tentang agama, syariat, dirinya dan pahamnya sendiri. Beliau menuturkan:

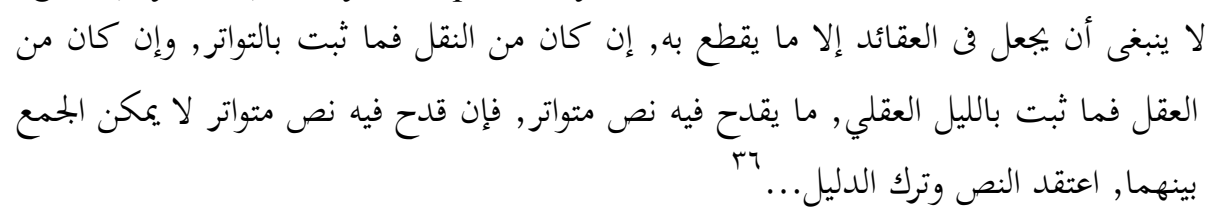

"Bahwa akidah dijelaskan melalui dalil pasti, bila berasal dari naql (alQur'an dan hadits mutawatir), atau akal maka harus dipastikan melalui dalil akal dengan catatan selama tidak bertentangan dengan nash yang mutawatir. Apabila terjadi pertentangan yan tidak dapat di padukan (jam'u) antara keduanya, maka yang diyakini adalah nas dan dalil akal ditinggalkan”.

Hal itu karena syariat merupakan:

$$
\text { هلك الشريعة هي المجة البيضاء, محجة السعداء, وطريق السعادة, من مشى عليها بنا, ومن تركها }
$$

"Sesungguhnya syariat adalah jalan lurus, jalan mereka yang bahagia, jalan keselamatan, siapa yang berjalan di atasnya akan selamat, dan siapa yang menjauhinya akan celaka".

Syariat itulah jalan menuju keselamatan. Yang ditegaskan Ibn 'Arabī bahwa ia adalah syariat yang digariskan Allah melalui Rasul-Nya.

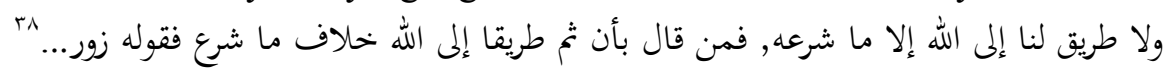

"Tidak ada jalan manapun menuju Allah kecuali jalan yang digariskan-Nya. Siapapun yang mengatakan ada jalan lain menuju Allah, berbeda dengan yang digariskan-Nya, maka ucapannya dusta..."

Syariat itu merupakan satu-satunya jalan menuju Allah. Bukan dari banyak jalan, bukan pula dari banyak ajaran. Apalagi dari banyak ajaran satu tujuan. Namun banyak ajaran yang berasal dari para nabi, bukan ajaran yang dibuat oleh selera masing-masing kepala. Bukan pula banyak agama satu Tuhan, namun dari banyak agama yang diridhai hanyalah satu Islam. Itu hanya bagi mereka yang beriman kepada Allah yang berfirman:

$$
\text { QS. Ali Imrān (19) }
$$

\footnotetext{
${ }^{36}$ Ibn 'Arabī, Futūhàt al-Makkiyah, vol.1, 465

${ }^{37} \mathrm{Ibn}$ 'Arabī, Futūhāt al-Makkiyah, vol.1, 69

${ }^{38}$ Ibn 'Arabi, Futūhàt al-Makkiyah, vol.2, 366
} 


$$
\begin{aligned}
& \text { إِنَّ الدِّينَ عِنْدَ اللَّهِهِ الإسنالام }
\end{aligned}
$$

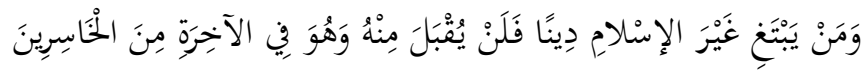

"Dan siapa yang mencari agama selain Islam, maka tidak akan diterima darinya, dan di akhirat ia termasuk golongan mereka yang merugi". Dan QS. Ali Imrān (67) yang menegaskan bahwa bapak para nabi ( $A b \bar{u}$ al-anbiyā'), Ibrahim adalah muslim, bukan Yahudi, bukan pula Kristen.

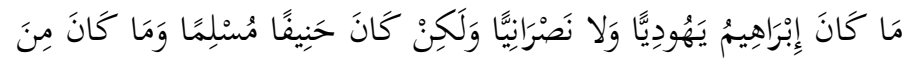

$$
\begin{aligned}
& \text { الْمُشْرِكِينَ }
\end{aligned}
$$

"Ibrahim bukan seorang Yahudi dan bukan (pula) seorang Nasrani, akan tetapi dia adalah seorang yang lurus lagi muslim dan sekali-kali dia tidak termasuk golongan orangorang musyrik".

Karena yang diterima Allah menurut Ibn 'Arabì, hanya satu yaitu syariat Islam. Klaim bahwa ada banyak jalan menuju Tuhan, adalah ungkapan dusta.

Syariat nabi Muhammad saw. yang diperintahkan Allah untuk diikuti.

$$
\begin{aligned}
& \text { (لقد كان فن رسول الله أسوة حسنة) فقتح وندبنا إلى التأسي به صلى الله عليه وسلم, وقال }
\end{aligned}
$$

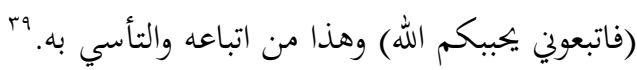

"Sungguh telah terdapat dalam diri Rasulullah suri teladan yang baik, maka Allah membuka dan menganjurkan kita untuk mengikuti Rasulullah saw. dan berfirman (Ikutilah aku -rasul- maka Allah akan mencinta kalian semua".

Setelah Ibn 'Arabi menjelaskan secara tegas posisinya tentang agama dan menolak keras klaim pluralisme yang dituduhkan, masih tersisa pertanyaan tentang maksud agama cinta dalam gubahan syair di atas. Abd Wahhāb al-Sha'rāni menjelaskan: Yang dimaksudkan Ibn 'Arabi pada redaksi di atas bukanlah pembenar terhadap semua agama (pluralisme), namun ia ingin menjelaskan bahwa saat dia berada pada tahapan alam persaksian hati (al-Shuhūd al-Qalbī) menyaksikan bahwa Allah adalah Pencipta segala semua yang ada, Dia mengetahui segala keyakinan yang dianut manusia, dan setiap keyakinan ini tidak terlepas dari ilmu dan menyimpang dari keinginan Allah swt. Maka Ibn 'Arabī mencintai semua

\footnotetext{
${ }^{39}$ Ibn 'Arabì, al-Tadbìrāt al-Ilāhiyyāt, 145
} 
Ibn 'arabī; Epistemologi dan kontroversi

makhluk Allah sebagai makhluk-Nya, karena mereka juga mencintai Allah. Dan baginya tidak ada halangan menjadikan cinta sebagai perantara mendekatkan diri kepada Allah. ${ }^{40}$

Perlu dibedakan antara posisi Ibn 'Arabi saat mengalami al-Shuhūd al-Qalbỉ seperti di atas, dan posisi beliau saat dalam kondisi biasa. Ibn 'Arabi hanya mencintai makhluk Allah sebagai makhluk-Nya, bukan membenarkan perilaku menyimpang yang dilakukan mereka. Hal ini jelas terungkap dari penegasannya bahwa Kristen telah kafir saat mengklaim trinitas. ${ }^{41}$ Begitupun kritikannya terhadap Yahudi, apalagi kaum penyembah berhala. Karena mereka semua tidak mengikuti ajaran Rasul saw. Padahal syari'at Nabi Muhammad bersifat nāsikhah (menghapus) syariat terdahulu. Sambil mengutip hadits: Law kāna Musa hayyan la mā wasi'ahū illāalItbia' $i^{42}$

\section{Ibn 'Arabì dan Wihdat al-Wujūd}

Tentang wihdat al-wujūd yang populer dinisbatkan kepada Ibn 'Arabì, dan karena sikap ini, beliau dianggap telah kafir, sesat oleh sebagian ulama muslim. Untuk menjelaskan semua itu dan memberikan sudut pandang lain tentang sosok beliau, biarkan Ibn 'Arabi berbicara sendiri tentang tuduhan ittihä tersebut.

Ibn 'Arabī mengkritik paham hulūl (Allah bersemayam dalam diri makhluk) dan ittihäd (bersat unya pencipta dan ciptan-Nya). Ia sampaikan:

$$
\text { من قال بالحلول فهو معلول, وهو مرض لا دواء لدائه, ولا طبيب يسعى فن شفائه. بـ }
$$

"Siapapun yang mengklaim hulül, maka ia sedang sakit. Hulūl adalah penyakit yang tidak dapat diobati, dan tidak ada dokter yang mau mengobatinya".

$$
\text { وما قال بالإتحاد إلا أهل الإلحاد. ؛؛ }
$$

"Dan tiada yang mengklaim ittihād/wihdat al-wujūd kecuali ia telah kafir".

Kemudian dia tegaskan melalui syairnya:

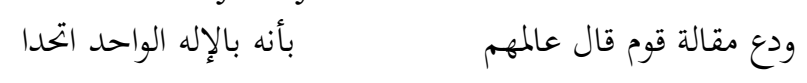

${ }^{40}$ Al-Sha'rānì, al-Ṭabaqāt al-Kubrā, Tarjamah Ibn 'Arabī, juz. 2, t.t.p, 177

${ }^{41}$ Abd al-Wahhāb al-Sha'rānī, al-Yawāqit wa al-Jawāhir fì Bayān 'Aqāid al-Akābir, t.tp, 28/ 36

${ }^{42}$ Ibn 'Arabī, Futūhāt al-Makkiyah, bab 36: fì ma'rifati 'Isāwiyyīn wa aqtabihim wa ușülihim...

${ }_{44}^{43}$ Ibn 'Arabī, Futūhāt al-Makkiyah, vol .4, 379

${ }^{44} \mathrm{Ibn}$ 'Arabì, Futūhàt al-Makkiyah, vol.4, 372 


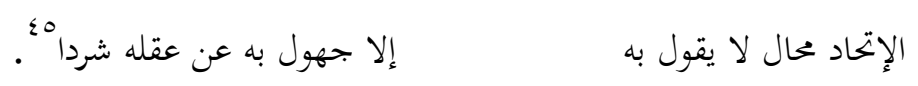

Artinya:

Tinggalkan ucapan pemuka kaum

Bahwa ia telah bersatu dengan Tuhannya

Ittihād tidak mungkin diucapkan

kecuali oleh mereka yang bodoh dengan akal terlepas

Bagi Ibn 'Arabi, sebagaimana Tuhan tidak mungkin menjadi hamba, begitupun sebaliknya. Karena Tuhan dengan Dzat-Nya adalah Tuhan. Hamba tidak boleh bersifat seperti Tuhan, kebersatuan tersebut tidak mungkin terjadi pada sifat hakiki antara keduanya.

$$
\begin{aligned}
& \text { فكما لا يكون الرب عبدا, كذلك لا يكون العبد ربا, لأنه لنفسه هو عبد, كما أن الرب لذاته }
\end{aligned}
$$

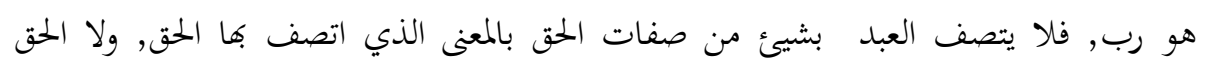

$$
\begin{aligned}
& \text { يتصف بما هو حقيقة للعبد.... }
\end{aligned}
$$

"Sebagaimana Tuhan tidak mungkin menjadi hamba, begitupun sebaliknya hamba tidak bisa menjadi Tuhan, karena diri hamba adalah hamba, sedangkan Tuhan dengan Dzat-Nya adalah Tuhan. Maka tidak mungkin hamba mempunyai sifat yang sama seperti Tuhan sebagaimana sifat Tuhan, begitu pula Tuhan, tidak mungkin memiliki sifat yang menjadi hakikat hamba".

Ibn 'Arabì menjelaskan bahwa setiap dua hal yang kontradiktif, seberapapun perbedaannya, pasti ada unsur penyatu (jami') yang mempersatukannya, kecuali hamba dan Tuhan. Karena keduanya memang amat sangat berbeda.

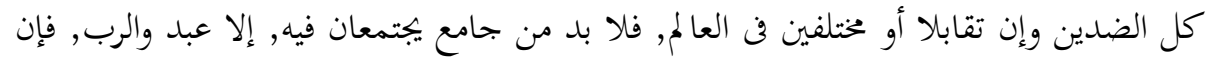

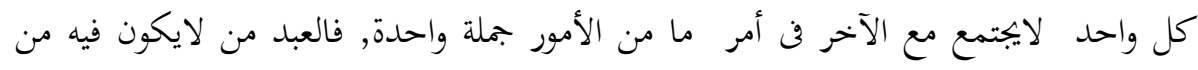

$$
\begin{aligned}
& \text { الربوبية وجه, والرب من لا يكون فيه من العبودية وجه. }
\end{aligned}
$$

"Setiap dua hal di alam raya ini yang kontradiktif seberapa jauh pertentangan dan perbedaannya, maka pasti punya unsur penyatu yang dapat menyatukan keduanya, kecuali hamba dan Tuhan. Sebab keduanya tidak mungkin bersatu dalam perkara apapun. Hamba adalah ia yang tidak punya sisi apapun dalam unsur ketuhanan, begitupun Tuhan adalah Ia tidak mempunyai unsur hamba".

\footnotetext{
${ }^{45}$ Ibn 'Arabī, Dīwān al-Shaikh al-Akbar, 441

${ }^{46}$ Ibn 'Arabī, Futūhāt al-Makkiyah, vo.1, 366

${ }^{47} \mathrm{Ibn}$ 'Arabì, Futūhāt al-Makkiyah, vol.1,371
} 
Disisi lain, Ibn 'Arabì menuturkan bahwa kemungkinan Ittihād hanya pada dimensi 'adad (bilangan) dan tabi' 'ah (alam). Kebersatuan tersebut bukan ittihàd mutlak, melebur, namun ada satu sisi di mana hamba dan Allah dianggap satu kerena berasal dari Yang Satu. Misalnya bahwa sifatsifat manusia berasal dari sifat ketuhanan (man'unatu al-rubūbiyyah). ${ }^{48}$ Itihād yang dimaksudkan adalah dari satu sisi, kesamaan terbatas, bukan mutlak. Karena keterbatasan itulah, kesamaan dalam sisi tersebut tidak dapat menyatukan atau memadukan antara keduanya. Tuhan pada Dzat-Nya adalah Tuhan, dan hamba tetaplah dirinya menjadi hamba.

Kebersatuan antara hamba dan Tuhan bagi Ibn 'Arabì adalah sebuah kondisi di mana hamba melihat semua realitas berasal dari Tuhan Yang Satu. Dan hal tersebut hanya berada pada ranah 'adad dan tabí'ah bukan dalam hakikat.

حال. الإتحاد تصيير الذاتين ذاتا واحدة, إما عبد وإما رب, ولا يكون إلا فن العدد وفن الطبيعة, وهو

Seperti bersatunya $1+1$, bilangan ini tetaplah terbentuk dari dua bilangan, yaitu 1 dan 1 . Kedua adalah menyatu membentuk bilangan (fainnah $\bar{u}$ wāhidan), keduanya satu namun di dua posisi (fainnahū al-wāhid fí martabataini) Contoh di alam raya, seperti bersatunya oksigen dan hidrogen yang membentuk air. ${ }^{50}$

Sebagaimana juga dijelaskan QS. al-Anfāl (17). ${ }^{51}$ Pada ayat itu, jika dikatakan bahwa yang melempar adalah Nabi Muhammad, itu benar, pun juga jika disebut bahwa yang melempar adalah Allah juga benar. Ittihād pada lafadz al-ramyu, bahwa Allah dan nabi Muhammad yang melakukannya adalah sah dinisbatkan kepada Nabi Muhammad dan Allah swt. ${ }^{52}$ Persatuan dalam kata al-ramyu saja, bahwa Allah yang melakukannya dan begitupun Nabi. Namun kuasa Allah yang menggerakkan Nabi, otoritas Allah yang menciptakan segalanya.

Wihdāt al-wujūd dalam pandangan kaum sufi berbeda dengan pandangan Barat dan Kristen. Karena kaum sufi membedakan antara Allah

${ }^{48} \mathrm{Ibn}$ 'Arabī, Futūhàt al-Makkiyah, vol.1,41

${ }^{49} \mathrm{Ibn}$ 'Arabīi, Futūhāt al-Makkiyah, vol. 2, 130

${ }^{50}$ Mahmūd al-Gharrāb, al-Raddu 'alā Ibn Taimiyah, min Kalām al-Shaikh al-Akbar, 104

${ }^{51}$ Allah berfirman QS. al-Anfâl (17):

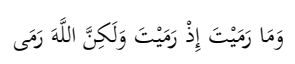

Ayat ini turun berkaitan dengan lemparan kemenangan Nabi pada perang Badr yang menjelaskan otoritas kuasa Allah Yang Esa, tiada yang lain. Ibn Kathir, Tafsir al-Qur'än al'Azīim, Dār al-Thaibah li al-Nashr wa al-Tauzi', vol.4, hlm. 31

${ }^{52}$ İbn Kathīi, Tafsìr al-Qur'ān al- 'Azīm, vol.4,(Dār al-Thaibah li al-Nashr wa al-Tauzì'), 109 
dan alam. Mereka melihat bahwa alam yang tampak ini tidak mempunyai wujud secara hakiki, karena wujud hakiki hanya milik Allah, maka Allah bukanlah alam dan alam bukan Allah. ${ }^{53}$

Maksud ungkapan Ibn 'Arabī dengan :

$$
\text { ويعبدني وأعبده : }
$$

$$
\text { فيحمدني وأحمده }
$$

Artinya:

Maka ia memujiku

Sebab aku memuja-Nya

Dan Dia memperkenankan permintaanku (melayaniku) ${ }^{54}$. Karena aku menyembah-Nya adalah bahwa Allah memberikanya pujian karena ia telah memujinya, dan memperkenankan (al-táah) permintaannya karena ia telah menyembah-Nya. ${ }^{55}$ Bukan berarti Ibn 'Arabì menempatkan Allah dan dirinya sama secara mutlak, namun sama dalam kata "yahmadu" dan "ya'budu" pada posisinya masing-masing, posisi "yahmadu" dan "ya'budu" bagi hamba dan posisi "yahmadu” dan "ya'budu” bagi Tuhan Sang Pencipta.

Ilustrasi lain yang dikemukakan Ibn 'Arabi untuk menjelaskan konsep ittihād-nya ini adalah tentang puasa dan pahalanya. Melalui gubahan syair:

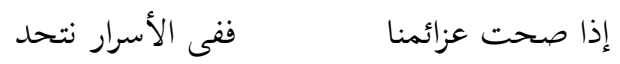

Artinya:

Jika niat kesungguhan kita adalah benar maka di alam rahasia kami akan bersatu.

$$
\text { هو العزيمة النية, والنية شرط فن الصوم, فنحن فن الصوم مع الحق, كما قالت بلقيس فن عرشها (كأنه }
$$

${ }^{53}$ Țāhā Abd al-Bāqī Surūr, A'lām al-Tașawuf al-Islamīi, vol. 1,85

${ }^{54}$ Kata "ya'budu" digunakan dalam konteks bahwa Allah "melayani" keinginan Ibn 'Arabì setelah ia menyembah Allah swt.

${ }_{55}$ Abd al-Hafiż, A'täm al-'Arab: al-Shaikh al-Akbar, Muhyiddìn Ibn 'Arabī, Sultān al'Árifîn, (Kairo: Hay-ah al-Mishriyah li al-Kitab, 1986M),161

${ }^{56}$ Ibn 'Arabī, Futūhàt al-Makkiyah..., vol. 1, 496 
Ibn 'arabi; Epistemologi dan kontroversi

Artinya: 'azimah adalah niat yang merupakan syarat sahnya puasa. Maka sebenarnya dalam puasa kita bersama Allah (al-Haq), sebagaimana ungkapan Bilqis tentang singgasananya: Sepertinya ia memang singgasanaku. Allah berfirman: puasa adalah punyaku bukan punya kamu, inilah maksud dari gubahan sya'ir di atas.

Maka, benar jika engkau berkata: yang berpuasa adalah manusia. Pun juga benar jika engkau berkata bahwa puasa adalah milik Allah bukan manusia. Jadi maksud ittihād di sini hanyalah keabsahan penisbatan terhadap keduanya, disertai pembedaan antara satu dengan lainnya dalam hakikat persatuan ('ain al-ittihäd), manusia -dalam penisbatan tersebutsama dengan Dia, namun di satu sisi manusia-pada hakikatnya ('ain alittihād) bukanlah Dia.

Bahwa saat niat puasa menjadi sah, maka pahalanya akan diberikan oleh Allah. Dalam puasa, al-Șäim sedang bersama Allah. Jika dikatakan bahwa manusia yang berpuasa, adalah benar, dan ungkapan bahwa puasa adalah milik Allah bukan manusia, pun juga benar. Tidak ada penghalang antara keduanya, dan penisbatan menjadi sah, namun tetap disertai pemisahan antara keduanya pada esensi ittihäd, Allah tetaplah Allah dan begitupun hamba.

Penjelasan Ibn 'Arabì di atas sangat filosofis, maka diperlukan kejelian dan ketelitian dalam memahami dan mencernanya. Apalagi tegas di sebutkan Ibn 'Arabī sendiri bahwa pandangannya tidak berdiri hanya pada satu kata, ia terikat dan terkait dengan kata-kata lain yang disampaikannya. Saat di awal, tegas disampaikan bahwa Tuhan dan hamba tidak akan dan tidak mungkin bersatu, paham hulül dan ittihäd jelas menyimpang dari ajaran Allah dan petunjuk Rasul mulia, tentu tidak mungkin Ibn 'Arabi pada kesempatan lain mengingkari pandangan sebelumnya.

Maka istilah "ittihād” kedua yang digunakan Ibn 'Arabi tentu tidak sama dengan "ittihad" pertama yang dikritiknya, begitu seterusnya, karena penulis masih menyakini bahwa Ibn 'Arabi merupakan tokoh shufi besar yang menjadi rujukan tasawuf dalam dunia Islam secara umum.

Tapi, betapapun deskripsi Ibn 'Arabi tentang ittihäd yang jelas dan lugas, kata tersebut bagi sebagian dan mungkin banyak kalangan masih dianggap sangat kontroversial. Banyak kalangan menerjemahkan ittihād dimaksud dengan wihdāt al-wujūd, padahal Ibn 'Arabi tidak pernah menyebutkan istilah ini.

Maka tetap saja wihdāt al-wujūd dalam pengertian luasnya masih dianggap kebersatuan antara Tuhan dan makhluk-Nya secara mutlak. Untuk alasan itulah, Sa'ìd Ramaḍān al-Būṭī menolak wihdāt al-wujūd dan menggantinya dengan konsep wihdät al-Shuhüd. Yaitu kondisi dimana 
Ibn 'arabī; Epistemologi dan kontroversi

makhluk melihat realitas wujud berasal dari satu entitas yaitu Allah swt. Ia ilustrasikan seperti saat manusia melihat keindahan taman, keharuman bunga yang mekar, aneka ragam tanaman yang ada di dalamnya, ia senantiasa mengingat, tidak melupakan Penciptanya yang pastinya lebih indah dari itu semua. ${ }^{57}$

Tuduhan lain tentang paham trinitas yang dianut oleh Ibn 'Arabi seperti disampaikan Miguel Asin Palacios (El Islam Cristianizado, 1931) yang dikuatkan Abū al'Ulā al-'Afifí ${ }^{58}$ tentang paham trinitas (tathlith) telah dibahas tuntas oleh al-Sha'rānì dalam "al-Yāqit wa al-Jawāhir", dan kaitan konsep tathlith tersebut dengan terciptanya alam raya (al-khalq wa al-intäj).

Bahwa Ibn 'Arabi memaksudkan konsep tathlith-nya untuk menjelaskan betapa Esanya Allah yang selalu berada dan bersama makhlukNya dalam keesan-Nya. Seperti persaksian Ibn 'Arabi sendiri:

$$
\text { ما كا ظفر القائل بالثلاثة, وإنما كفر بقوله أن الله ثالث ثلاثة, فلو قال ثالث اثنين لأصاب الحق... }
$$

"Bahwa seorang tidak kafir karena mengucapkan al-Thaläthah", namun ia kafir karena mengucapkan Allah bersatu dalam tiga. Seandainya ia berkata Allah yang ketiga dari dua ${ }^{61}$, maka tentu ucapannya tepat. Apa pendapatmu tentang dua orang dan Allah adalah yang ketiga ${ }^{62}$, maksudnya Allah menjaga keduanya di dalam gua, pada masa hijrah".

Bagaimanapun, dalam menganalisa setiap karya Ibn 'Arabi diperlukan tindakan selektif dan teliti. Karena kitab Ibn 'Arabi banyak dimanipulasi oleh pihak yang tidak bertanggung jawab.

$$
\text { وكم صحف الكتاب قولا وحرفوا وجائوا بشيئ لم يرده المؤلف }
$$

${ }^{57}$ Al-Būțì, Hādhā Wālidĭ. Al-Qissah al-Kāmilah li Hayāt al-Shaikh Mullā Ramadān min Wilādatihì Ilā Wafătihì, Beirut: Dār Al-Fikr, 1995), 100

${ }^{58} \mathrm{Abu}$ al'Ulā al-'Afífi, Nazariyāt al-Islāmiyyīn fì al-Kalimah, 68-69

${ }^{59}$ Abd al-Wahhāb al-Sha'rānī, al-Yawāqit wa al-Jawāhir fì Bayān 'Aqāid al-Akābir, 28/ 36

${ }^{60}$ Mengucapkan Allah adalah yang ketiga dari dua orang.

${ }^{61}$ Senada dengan pernyataan ini adalah firman Allah pada QS: al-Mujādilah (7):

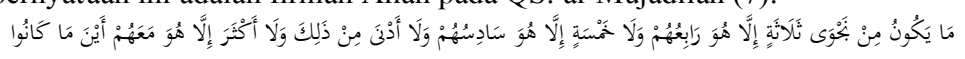

Artinya: Tiada pembicaraan rahasia antara tiga orang, melainkan Dia-lah keempatnya. dan tiada (pembicaraan antara) lima orang, melainkan Dia-lah keenamnya. dan tiada (pula) pembicaraan antara jumlah yang kurang dari itu atau lebih banyak, melainkan Dia berada bersama mereka di manapun mereka berada.

${ }^{62}$ Sabda Rasul saw. kepada Abū Bakar, menenangkan dan meyakinkannya:

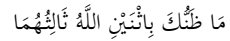

Hadis riwayat al-Bukhāri, Sahīh al-Bukhārī,bab Qauluhū Thāniya Ithnaini Idhhumā fì alGhär, hadis no. 4295 
Ibn 'arabi, Epistemologi dan kontroversi

\section{Epilog}

a. Kesimpulan

Dari uraian panjang di atas dapat disimpulkan bahwa:

1. Epistemologi Ibn 'Arabī menempatkan wahyu al-nuṣụs almutawatirah sebagai barometer dan penyeleksi kebenaran yang diterima oleh akal dan panca indera

2. Bagi Ibn 'Arabì, mausia dapat mengetahui kebenaran.

3. Klaim pluralisme, perenialisme, transenden unity of religions yang disampaikan Chittick, Schuon, Husein Nașr, Naṣr Hāmid Abü Zaỉd tidak kuat dan terbantahkan.

4. Klaim tersebut bersifat parsial karena hanya berdasar pada satu syair Ibn "Arabī pada "Tarjumān al-Ashwāq" seraya mengabaikan pandangan Ibn 'Arabi di karyanya yang lain.

5. Ibn 'Arabì menolak pluralisme dan wihdàt al-wujūd mutlak. Ittihād yang dimaksudkan Ibn 'Arabì adalah ittihäd parsial.

6. Ibn 'Arabi dalam akidah mengikuti nas, tuntunan dan arahan dari Allah, dan Syariat Nabi Muhammad. Jika bertentangan dengan nas tersebut, maka yang diambil adalah nas.

7. Untuk alasan menghilangkan kontroversi dan mencegah kesalahpahaman, maka istilah wihdāt al-wujud tidak lagi digunakan di masyarakat luas, dan diganti dengan wihdāt alshuhūd.

\section{b. Saran}

Berdasarkan hasil penelitian di atas, maka disarankan hal-hal berikut ini:

1. Bagi kritikus tasawuf untuk kembali membaca, menelaah dan menganalisa hakikat tasawuf, karena epistemologi sufi dibangun berdasarkan al-Qur'an dan hadis Nabi. Dalam kajiannya, Nabi Muhammad disebut insān kāmil yang harus diteladani.

2. Klaim tentang Ibn 'Arabī yang kontroversi, perlu segera dicabut dan dibaca ulang. Karena Ibn 'Arabì begitu menekankan pentingnya mengikuti Allah, sunnah Rasul saw. Kontroversi ekstrem kanan yang mencela dan mengkafirkan Ibn 'Arabi karena dianggap pencetus wihdāt al-wujūd dan lainnya, serta klaim ekstrem kiri yang menempatkan sebagai pembangun agama baru bernama cinta, perennial dan pluralis, pengusung paham transenden unity of religions. Karena Ibn 'Arabi, Tasawuf dan para ulamanya jauh dari itu semua. 
Ibn 'arabi, Epistemologi dan kontroversi

\section{Daftar Pustaka}

Adi, Rianto, Metodologi Penelitian Sosial dan Hukum, Jakarta: Granit, 2004

Agama, Departemen. Al-Qur'an dan Terjemahannya, Bandung: CV Penerbit J-ART, 2004.

'Arabī, Ibn. Rasāil Ibn 'Arabīi. Sharh Mabdai al-Ṭấān wa Rasāil Ukhrā, Abū Dabi: Majma' al-Thaqậi, 1998 M. , Al-Dhakhāir al-A'laq fí Sharh Tarjumān al-Ashwāq, Kairo, t.tp

al-Ghazali,Abu Hamid, Futūhàt al-Makkiyah, ed. Osman Yahia, Kairo: AlHa'at al-Mishriyyah al-'`Āmmah li al-Kitab, $1997 \mathrm{M}$. www.ghali.org, t.t.

Arif, Syamsuddin, Orientalis dan Diabolisme Pemikiran, Jakarta: Gema Insani, $2008 \mathrm{M}$.

Al-Bukhārì, Sahīh al-Bukhārī, Pustaka Dār Al-Khair, 1996.

Al-Buțī, Sa’ìd Ramaḍ̄an, Hādhā Wālidì: Al-Qișsah al-Kāmilah li Hayāt alShaīkh Mullā Ramaụān min Wilādatihì Ilā Wafătihï, Beirut: Dār alFikr, 1995 M.

---------------------, Kubrā al-Yaqīniyyāt al-Kauniyah: Wujūd al-Khāliq wa Wazîfät al-Maklūq", Damaskus: Dār al-Fikr, 1997 M.

Chtittick C. William, Dunia Imajinal Ibn 'Arabï: Kreativitas Imajinasi dan Persoalan Diversitas Agama, terj. Ahmad Syahid, Surabaya: Risalah Gusti, $2001 \mathrm{M}$.

Hafidz,Abdul, A'lâm al-'Arab: al-Syeikh al-Akbar, Muhyiddin Ibn 'Arabî, Sulthân al-'Arifîn, Mesir; Hay-ah al-Mihriyah li al-Kitab, 1986 M.

Al-Hefni, Abdul Mun'im, al-Mausu'ah al-Shufiyah, Kairo: Dar al-Rasyad, $1992 \mathrm{M}$.

Husaini, Adian, Tinjauan Historis: Konflik Yahudi-Kristen-Islam, Jakarta: Gema Insani Press, $2004 \mathrm{M}$

Kathïr Ibn, Tafsìr al-Qur'ān al- 'Ażìm, Dār al-Ṭaybah, 1422 H.

Kunto, Ari dan Suharsimi, Prosedur Penelitian; Suatu Pendekatan Praktek, cet. ke-10, Jakarta: PT Rineka Cipta, 1996.

Miguel Asin Palacios, terj. Abdurrahman al-Badawi, Ibn 'Arabî: Hayatuhu wa Madzhabahu, Makatabah Injilo al-Mishriyah, 1965 M.

Nashr Hamid, Abu Zaid, Hakadza Takallama Ibn 'Arabî, Mesir: al-Hay-ah al-Mishriyah al-'Ammah li al-Kitab, $2002 \mathrm{M}$

Al-Qurțūbì, Al-Jāmi’ li Ahkām al-Qur'ān, Riyāḍ: Dār al-‘Alam al-Kutub, $1423 \mathrm{H}$.

Al-Sha'rānì, Abd al-Wahhāb, al-Ṭabaqāt al-Kubrā, Tarjamah Ibn 'Arabī, Dār al-Șadr, 2003 M. 
al-Yawāqit wa al-Jawāhir fỉ Bayān 'Aqāid al-Akābir, Dār al-Ṣadr, 2003 M. S. Sumatri, Juju, Filsafat Ilmu: Sebuah Pengantar Populer, Jakarta; Pustaka Sinar Harapan, 1988.

Sudatro, Metode Penelitian Filsafat, Jakarta: Raja Grafindo Persada, 1996.

Yūsuf, Muhammad 'Ali Haj. Shams al-Maghrib: Sirat Shaikh al-Akbar Ibn 'Arabī wa Madhhabuhū, Suriyah, Halb 'Āṣimah li al-Thaqāfah alIlmiyah, $2006 \mathrm{M} / 1427 \mathrm{H}$. 